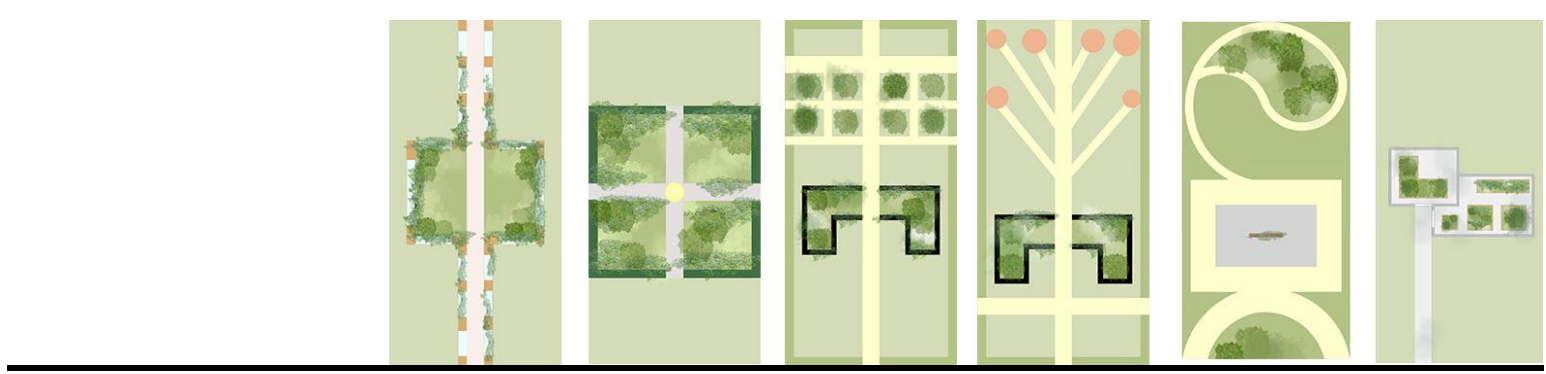

DOI: 10.21005/pif.2021.46.C-03

\title{
THE ROAD AS AN ESSENTIAL ELEMENT OF THE CONTENT OF THE SHOW GARDEN
}

DROGA JAKO ISTOTNY ELEMENT TREŚCI OGRODU POKAZOWEGO

\author{
Izabela Myszka \\ Doktor inżynier \\ Author's Orcid number: 0000-0002-8820-4053 \\ Katarzyna Augustyniak \\ Magister inżynier \\ Author's Orcid number: 0000-0003-2422-268X
}

Szkoła Główna Gospodarstwa Wiejskiego w Warszawie

Wydział Budownictwa i Inżynierii Środowiska

Katedra Sztuki Krajobrazu

\begin{abstract}
In this article, we focus on the subject of the show garden and place for path in the garden, in particular its forms and functions in space and meaning. The form and function of path was examined on the basis of selected, representative examples of historical gardens and contemporary show gardens of the festival in Chaumont-sur-Loire. The results showed that a path is the leading element of every garden, and its form has a decisive influence on the composition of the entire space and allows you to note content. Based on the research results, road system diagrams in historical gardens were developed and model concepts for show gardens inspired by the history of gardens were developed. The currently very touching topic of Quarantine has become the leitmotif of the garden content.
\end{abstract}

Keywords: road in historical gardens, garden elements, show garden during quarantine.

\section{STRESZCZENIE}

W niniejszym artykule skupiamy się na tematyce ogrodu pokazowego i drogi w ogrodzie, a w szczególności jej form i funkcji w przestrzeni oraz znaczeń. Forma oraz funkcja drogi została zbadana na przykładzie wybranych, reprezentatywnych przykładów ogrodów historycznych oraz współczesnych ogrodów pokazowych festiwalu w Chaumont-sur-Loire. Wyniki wykazały, że droga jest elementem wiodącym każdego ogrodu, a jej forma ma decydujący wpływ na kompozycję całej przestrzeni i pozwala notować treści. Na podstawie wyników badań opracowano schematy układów drogowych w ogrodach historycznych i wypracowano modelowe koncepcje ogrodów pokazowych inspirowanych historią ogrodów. Motywem przewodnim dla ogrodowej treści stał się aktualnie bardzo poruszający temat Kwarantanna.

Słowa kluczowe: droga w ogrodach historycznych, elementy ogrodowe, ogród pokazowy w kwarantannie. 


\section{THE SHOW GARDEN AS A WORK OF ART. THE ROAD AS A NARRATION}

Lockdown has recently become the biggest social and cultural problem. It touched all areas of life in various ways. Will it have an impact on landscape architecture? Looking for an answer to this question, we try to create a concept of show gardens in the times of lockdown, and draw inspiration for this topic from the history of changes in the art of gardening.

The main feature of a show garden is its reflection on perceiving and building space, which becomes the creator's statement on a specific topic. It pictures one's value system and the way of seeing the world. Artists who create show gardens as works of art focus on conveying them in the form of thoughtful content (Myszka-Stąpór, 2018). Show gardens are therefore a special example of a space in which the language of forms is used to write current content in the social discourse ${ }^{1}$. They function as separated from the space of the work, regardless of their surroundings. Their existence is by definition temporary. They exist in the festival space as forms visually independent of their surroundings. Their existence is not necessarily related to environmental and compositional analyzes, which are usually dictated by spatial solutions in "normal", non-show garden works (Myszka-Stąpór, 2017). Show garden concepts are very often presented as freehand drawings ${ }^{2}$. It happens that from a garden festival, which is a specific art exhibition, the show garden is copied into another space (Herman, 2011). Show gardens are a good example of the importance of each individual element of the garden. According to Jan Rylke (2010b), festival gardens are a kind of model for contemporary private gardens. Garden festivals are therefore indicators of trends and tendencies in space design (Rosłon-Szeryńska, Pieńkowska, 2010).

Based on the assumptions that the road in the garden is a canvas for the composition of the remaining forms (Myszka-Stąpór, 2018), we decided to analyze the forms of paths in historical and contemporary assumptions, in order to illustrate the contemporary, pressing problem of global lockdown. Paths in the garden do not only enable mobility, but also structure the space. They are meant to lead to specific places and zones. Create the core of the garden, allowing you to see the surroundings (Goodchild, 2008). Paths sustain composition and combine functional zones in the garden. They establish order among other garden elements, as well as define the boundaries of garden interiors.

When analyzing the aspects of changes in the form, function and content of various garden elements, historians of garden art compare the function of path in garden to composition in a painting. One can distinguish scholars who take the road incidence from the perspective of garden art, such as Ciołek (1957), Bogdanowski (1978), Majdecki (2006), Hobhouse (2020), Różańska (2008). They discuss symbols and content written on the matter: Majdecka - Strzeżek (2008), Szafrańska (1998), 2011). Jan Rylke (1995) also mentions garden elements in his considerations on the secrets of gardens, he draws attention to roads and paths and their layout. For Rylke, the road is an archetype recognizable in all cultures, in time and space. Paths refer to both material meanings, and on the other hand, and a number of metaphorical meanings that refer to higher, metaphysical values (Ożóg, 2011).

Paths enable us to create the composition of the garden. The style of the garden then depends on its form and diversity. It is possible to make the style and content easier to read by the means of drawing paths and to complement this drawing with elements such as plant compositions, architecture and functional elements, treated as means of expression in show gardens. Thus, it can be argued that path is originally the most important element building the form and thus the content of a garden work.

\footnotetext{
${ }^{1}$ Garden festivals are organized annually in virtually in every country. Art garden exhibitions are very popular. Gardens are telling stories, they are about something. They are saturated with content. Sometimes the festival organizers dictate the leitmotif for all performances. This is the formula of the festival in Chaumont-sur-Loire.

${ }^{2}$ Freehand drawings are presented in the documentation of festivals, including at Chaumont-sur-Loire, Chelsea Flower Show and In Garden in Lublin, the first edition of which took place in 2020, source: http://www.domainechaumont.fr/fr/festival-international-des-jardins/archives; https://www.rhs.org.uk/shows-events/rhs-chelsea-flower-show, http://www.ingardeninlublin.com/, access: 31.03.2021.
} 
The aim of this paper is to determine the importance of path in the garden and its role in building the composition of the garden. This will enable the development of models of show gardens inspired by garden art created during lockdown. In the designs of show gardens, a path will be a compositional canvas, and its form will be characteristic of the type of garden, depending on the historical era.

\section{FORM AND CONTENT OF GARDEN SHOWS}

The state of the art review covers the history of garden art and contemporary show gardens. For the sake of clarity of the argument, it is necessary to define the concept of a show garden and the meanings encoded in the forms of garden elements. In line with the considerations included in the monograph entitled "Garden elements. Their form, function and meaning” (Myszka-Stąpór 2014, p. 31): festival gardens are described as garden works of art. The same term is also used in the research of Krzysztof Herman (2011), Kinga Zimowiec-Cieplik (2010), Jan Rylke (2010b, 2013b), and Iwona Wiśniewska (2010). „Garden of art.”, garden as a work of art, „garden - metaphor”, most often carried out as part of artistic and cultural events, the main goal of which, apart from the aesthetic layer itself, is to emphasize the symbolic layer, convey hidden content, the designer's message, the problem concerning modern world. Show gardens are created to become an inspiration, model, model for creating other spaces (Rosłon-Szeryńska, Pieńkowska, 2010). However, the importance of the garden element - in line with the considerations made in the monograph "Garden elements. Their form, function and meaning" (Myszka-Stąpór 2014, p. 22): each element intentionally used in the garden has a written meaning that can be read (...).

The function, form and meaning of garden elements are interrelated (Rylke, 2011a). Janusz Bogdanowski (2000) and Stanisław Ossowski (1958) write about their consistent treatment in the context of a garden work, noting that the composition should meet the conditions of the form, function and content of the work being created. The content in the garden is the determinant according to which gardens should be considered and not narrowed down to the composition only (Mitkowska, Łakomy, 2012). For the authors, not only the composition of the garden has a scientific and research value, but also an aesthetic one, functional and semantic layer. In the studies of Jeremy $T$. Królikowski $(1978,1998)$ the meaning written in space is defined as 'genius loci'. A similar way of interpreting the landscape was also presented by Edward Bartman (2009) and Janusz Bogdanowski (2001). Agata Zachariasz (2010b) describes and interprets the content of gardens of various cultures, so does Charles W. Moore, William J. Mitchell, William Turnbull Jr. (1993), who also analyze gardens of different cultures. Interestingly, Zachariasz especially emphasizes the relationship between the number of garden elements and the type of garden. Writing about contemporary trends and trends in garden art, she draws attention to the shape of the designed garden, which depends on the form, function and content ${ }^{3}$. According to Spirn (1998), interpreting meanings and contents that are written in space can be the basis for creating design guidelines. He calls the content of the landscape 'the language of the landscape'. This term is also found in the work of Elżbieta Raszeja (2009). Jane Gillette, Susan Herrington, Laurie Olin, Marc Treib (2011) also consider the content and meaning in the garden. Herrington, as a show garden designer for the Jardin de Metis festival in Canada, maintains a view of gardens that convey content to be read. Kinga Zinowiec - Cieplik (2010) also examines the content of the festival gardens. The importance of the elements and content of gardens is also discussed by Iwona Wiśniewska (2010). The subject of content in home gardens is taken up by Beata Gawryszewska (2006), who argues that symbolically marked elements are spaces that connect garden zones, i.e. "Passage spaces" and the path of honor. They are a good example that shows the importance of each individual element of the garden.

The meaning of the road can be considered not only in the symbolic context as a carrier of cultural content, but also in an useful and functional sense, which is particularly visible in the design process. Jan Rylke (2017), in a publication devoted to the principles of design, in one of the chapters,

\footnotetext{
${ }^{3}$ Zachariasz (2009): (...) form, content and function, and hence: stylistics, semantics, program, as well as technology and
} materials. 
as the first element from which to start designing, mentions the distinction of the main communication system from paths intended for walking, which indicates the exceptional, decisive importance of the road in composition and functionality space ${ }^{4}$. According to the research by Izabela Myszka Stąpór (2014), path is a structural element of the garden, i.e. makes it possible to accent elements, elements rhythmically arranged, decorative, and a rebate.

\section{HISTORICAL AND CONTEMPORARY ART GARDENS}

The material for preliminary research was iconography and iconology collected by historians of garden art. Road layout diagrams were prepared using the available historical garden plans.

The documentation of the Chaumont-sur-Loire Garden Festival in France was selected as the material for the analysis of contemporary path way solutions. The festival has been held annually since 1992. The gardens are presented in a separate space consisting of approximately 26 separate stands. Designers and artists from all over the world are invited to take part in the event. All the analyzed gardens have certain common features distinguished by the organizers of the festival. These include: the size and shape of the plot, the fence and the theme, the leitmotif. The diversity between individual gardens is visible in the selection of elements and in the composition layer, which depend not only on the idea expressed by a given garden, but also on the theme of the festival edition (Myszka-Stapór, 2014). The Chaumont-sur-Loire Festival Gardens were considered the most appropriate research material due to:

- presenting gardens as works of art that convey essential content,

- the possibility of interpreting the content and meanings conveyed by the authors due to the availability of comments and descriptions, drawings and photos.

The method of reading the meanings was the analysis of iconography and iconology developed by Edwin Panofsky (...) and Jan Białostocki (...), based on establishing framework topics for the analysis of a work of art. All works made in 2015-2019 were analyzed. Photographs, films, comments and descriptions of the gardens can be found in the catalog on the festival's website (http://www.domaine-chaumont.fr/en/international-garden-festival- realizations and projects). The method of interpreting the show garden is borrowed from art history as we assume that the show garden is a work of art. Interpretation follows the scheme: establishing framework themes, iconological and iconographic analyzes, defining garden elements used as means of expression in the work.

\section{THE MEANING OF THE ROAD IN THE GARDEN}

In all the analyzed historical and contemporary gardens there was a path that marked the composition, functional zones, divided the space, sometimes changing its form into a square or looping. As a result of the analysis of the iconography of historical gardens, diagrams were created showing path systems characteristic for individual epochs (Fig. 1).

Paths in the gardens of the festival in Chaumont-sur-Loire became a structuring element that created a composition. Designate divisions and zones. Lead to places. Bring you to the garden. Let's take a closer look at the garden. Paths indicate the next stops and nooks that execute the intended concept and vision of the creator. Paths sometimes develop into squares. They are made of various materials or are a combination of a paved surface with a meandering lawn or a gravel path. Detaching the road from the whole composition would result in losing the proportion, order, func-

\footnotetext{
4 Jan Rylke (2017) in the publication entitled "Theory and principles of design for landscape architects" in the chapter devoted to theoretical principles of design discusses the existing principles of space design, which have been used by designers since antiquity. The first rule is to separate communication from walking. He points out that to this day, mainly in larger garden arrangements, such as parks, straight and geometric roads are used for communication, and circular paths are intended for walks. The author gives the example of the Warsaw Ujazdowski Park and the design of a minimalist garden in Bolestraszyce, in which the division of roads into those with a communication and walking function was the basis of the entire project.
} 
tion, and also the deep metaphorical layer that characterizes show gardens. Their compositional and aesthetic value, and with it the metaphysical value, would then be impossible to read and interpret. Among the gardens of the festival in Chaumont-sur-Loire there are geometric and free routes. Geometric paths slightly dominate over free ones. In 2015, 2016 and 2017, their number clearly prevailed. In 2018 and 2019, gardens with a free, irregular layout began to dominate, with paths with a free and irregular layout.
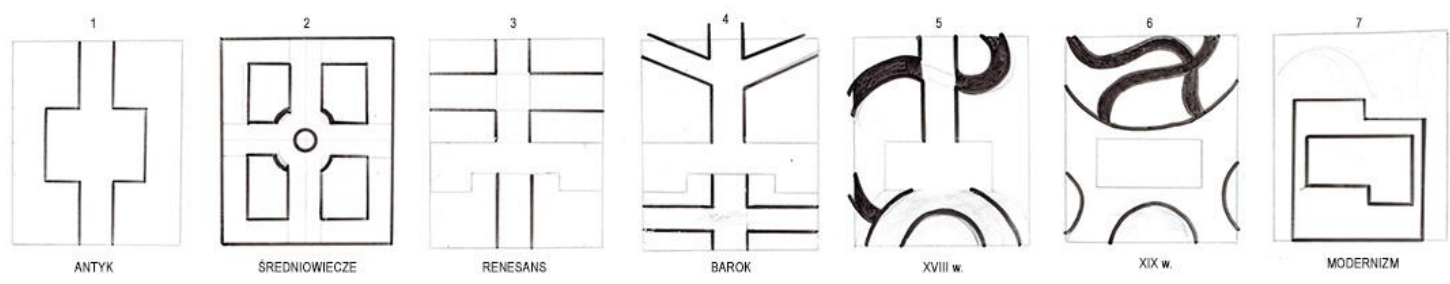

Fig. 1. Diagrams of the road layout in individual epochs: antiquity, medieval, renaissance, baroque, eighteenth century, nineteenth century, modernism. Source: author

Ryc. 1. Schematy układu dróg w poszczególnych epokach: antyk, średniowiecze, renesans, barok, XVIII w., XIX w., modernizm. Żródło: autor

The themes for the analyzed gardens from the last 5 years of the festival in Chaumont sur-Loire are: "Extraordinary Gardens, Collection Gardens", "Gardens of the Next Century", "Flower Power The Power of Flowers", "Gardens of Thoughts", "Paradise Gardens". In the gardens of the first three editions, the form and content of paths were less often referred to in the descriptions, and in the topics related to paradise and thoughts, almost every description defined the content assigned to paths. In the first edition, paths were emphasized only twice as a carrier of meanings. Six times in the second edition. In the third, seven times. In the fourth one in each garden - one of the gardens even had the title "The Endless Promenade" (Agathe Pichard, Agnès Emonet, Laurence Vincent-Pichard, 2018). In each of the descriptions of The Gardens of Thought, paths were emphasized as an important element. In the last of the analyzed editions, the vast majority of paths were presented as a process leading to well-being, which is to be associated with paradise and is an important element encoding meanings related to human behavior and human choices.

From the descriptions of the gardens one can read the role that paths played in their content and composition. Different forms of the paths were built of different substances, and thus had different contents. Firstly, paths were mentioned as a certain process of guidance, the moment of entering a path and ending the journey was emphasized. There was also a different presentation, a looped path that has no beginning or end, which referred directly to making life decisions and free will of every human being. The second aspect concerned the differentiation of space. In three of the analyzed gardens, the thread motif appeared as an attribute associated with the road, as in the myth about Ariadne and Theseus. Using such a narrative, it can be argued that a path divided the garden like a thread into different spaces with usually contrasting values. There were also contrasts that appeared just by wandering around the garden, in which subsequent stops were placed on the path, like beads woven into a single thread. The garden contrasts connected with the road were written in the substance - dry garden, wet garden, black or white colours, elevation and depression of the ground. The substance of the road was emphasized by materials affecting the sense of sight and touch, such as wood, glass, moss, sand. There were various obstacles on the path, which, apart from their symbolic layer, built the form. The path was sometimes geometric, winding, straight, main or side, which gave it archetypal significance and indicated differences in the way and complexity of human existence in the world. It also took the form of a labyrinth and a spiral path, which symbolized the decision-making process of a man who had the right to choose his own way. The path was also closed into a tunnel so that walking on it was more contemplative and secluded. In several gardens, the road rose upwards, thus emphasizing the earth-heaven axis as 
a kind of sacred. Here the path was presented as an allegory of wisdom and experience that lift man upwards.

\section{A GARDEN ABOUT A QUARANTINE. CONCLUSIONS}

Based on the research, model concepts for show gardens were drawn up, inspired by the epochs in the history of garden art. (Fig.2). Six garden models have been developed that represent successively the garden styles of the historical epochs. The theme of the concept of show gardens is 'lockdown' because it was recognized that in 2020 it is the most pressing topic. The road as a leading element in the subject of "Quarantine" is to show the passage through this difficult period, at the same time referring to the history of garden art. The developed models of show gardens prove that it is possible. The road was used as the main element expressing the content on a given topic and presented with reference to historical epochs. At this point, it should be emphasized that show gardens function as separated from the space of the work, regardless of the surroundings. Their existence is by definition temporary. Their creation is not necessarily related to environmental, functional and compositional analyzes, which are usually dictated by spatial solutions in "normal", non-show garden works (Myszka-Stąpór, 2017). Even concepts are very often presented as freehand drawings ${ }^{5}$.
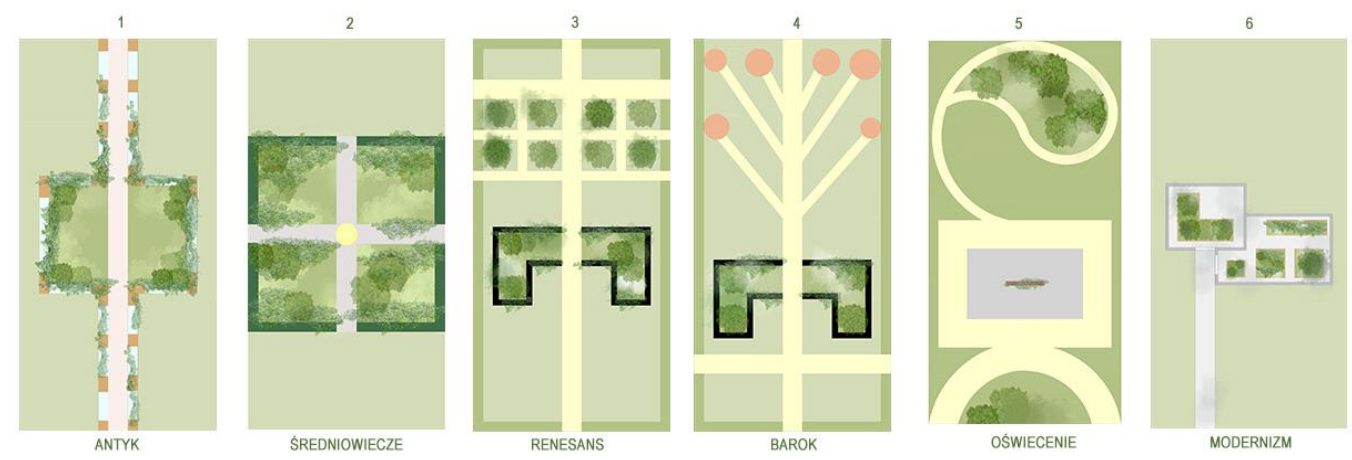

Fig. 2. Model concepts of show gardens for the theme "Quarantine" inspired by historical epochs: antiquity, medieval, renaissance, baroque, enlightenment, modernism. Source: author

Ryc. 2. Modelowe koncepcje ogrodów pokazowych dla tematu "Kwarantanna" inspirowanych epokami historycznymi: antyk, średniowiecze, renesans, barok, oświecenie, modernizm. Źródło: autor

In the antique-inspired garden model, path passes through the peristyle. The lockdown path is surrounded by walls, closed, isolated from the world. Only windows are left in it, which are the only ones that allow you to observe the surroundings and provide a substitute for contact with the world. Both the path and the peristyle, according to traditional patterns, are vertically open to the light of hope.

The cloisters in the Middle Ages were places intended mainly for prayer and contemplation. The cloister in the presented model is also a place of seclusion and isolation required by quarantine. In the center, at the crossing of paths, there is a light that symbolizes hope, which is of particular importance during lockdown. The patio is surrounded by a hedge that closes and isolates the space.

In a Renaissance garden, the path is the main axis that goes through the center - a closed lockdown space. In the further part of the garden, it crosses the cross paths, thus building the garden

\footnotetext{
${ }^{5}$ Freehand drawings are presented in the documentation of festivals, including at Chaumont-sur-Loire, Chelsea Flower Show and In Garden in Lublin, the first edition of which took place in 2020, source: http://www.domainechaumont.fr/fr/festival-international-des-jardins/archives; https://www.rhs.org.uk/shows-events/rhs-chelsea-flower-show, http://www.ingardeninlublin.com/, access: 31.03.2021.
} 
ground floors. We are close to the ground, in the imposed scheme we cultivate a closed garden, surrounded by a hedge. We only have one way in lockdown - from home to the garden.

Path in the Baroque garden is the main axis of the composition. It crosses transverse paths that diverge in a radial pattern, creating a "goose foot". The whole garden is closed and surrounded by a hedge, but the "upper" part, where the roads intersect, has been opened - analogous to traditional Baroque gardens, where the road led towards the view opening. So maybe there is some hope for opening?

The model of the landscape garden was created by combining the 18th and 19th century gardens, called in the model the garden of the Enlightenment. Path in the landscaped garden has a varied composition. Directly in the vicinity of the "home" it is geometric. In the rest of the garden, it takes a free form. In the place where the building has been symbolically marked, there is a door that emphasizes the moment of passage. The composition of the patch was designed in such a way as to create a closed, looped system, which makes it difficult to define its end. Looping the path is a reference to the state of lockdown. A man in quarantine can only move in a certain space. The looped path can also be symbolically interpreted as a situation with no way out.

In the modernist garden, the communication system is subordinated to the rules of minimalism, it is not as extensive as in the previous models. It is limited to one main path leading to two separate vegetable gardens. The gardens of the 20th century were primarily functional, hence the use of only utility plants in the concept that emphasize this function. The two vegetable gardens are intentionally separated from each other. It is a reference to a lockdown that requires isolation and closing oneself to the surroundings.

Concluding the importance of a path as an element in the garden, emphasize its importance in the aspects of communication, form and content. The layout of a path identifies the style of the era in garden art and also forms the framework of the garden. By dividing the space a path structures it. The creators of garden works, while reflecting on the change of the form and the way the paths are equipped, note various meanings, entangled in various frame themes and styles. Path is an element of the entire composition. It influences its reception and final form. What's more, it plays a key role in building harmony and balance. It organizes the space. It leads to specific places and zones. Paths set the rhythm and determine the importance of other garden elements. The layout of all garden interiors largely depends on its layout. The perspective from which the garden will be viewed depends primarily on the directions in which the paths will be led. The communication system is the backbone of the garden, its base, the board to which more are added complementary components. Often it is the path that marks the plot boundaries, so there is at the same time, a garden frame that opens and closes the composition.

The results of the work can be used for further interpretation of a path as a garden element, for the interpretation of entire garden assumptions and for further research. They make it possible to classify gardens on the basis of the paths and make it easier to recognize historical styles by the communication layout. The presented models can be an inspiration to create other spaces, as well as provide guidelines for leading a path in gardens inspired by the history of gardens.

\section{DROGA JAKO ISTOTNY ELEMENT TREŚCI OGRODU POKAZOWEGO}

\section{OGRÓD POKAZOWY JAKO DZIEŁO SZTUKI. DROGA JAKO NARRACJA}

Kwarantanna stała się w ostatnim czasie największym problemem społecznym i kulturowym. W różny sposób dotknęła wszystkich dziedzin życia. Czy będzie miała swoje przełożenie na architekturę krajobrazu? Poszukując odpowiedzi na to pytanie podejmujemy próbę wykreowania kon- 
cepcji ogrodów pokazowych, których tematem jest przejście przez kwarantannę, a inspirację dla tego tematu czerpiemy z historii przemian w sztuce ogrodowej. Specyfika ogrodów pokazowych jest odzwierciedleniem sposobu pojmowania i budowania przestrzeni, która staje się wypowiedzią twórcy w określonym temacie. Jest też zobrazowaniem systemu wartości oraz sposobu postrzegania świata. Artyści tworzący ogrody pokazowe jako dzieła sztuki skupiają się na przekazaniu w formie zamyślonej treści (Myszka-Stąpór, 2018). Ogrody pokazowe są zatem szczególnym przykładem przestrzeni, w której językiem form zapisywane są treści ważne w dyskursie społecznym ${ }^{6}$. Funkcjonuja jako wyodrębnione z przestrzeni dzieła, niezależnie od otoczenia. Ich bytowanie jest $\mathrm{z}$ założenia tymczasowe. Istnieją $\mathrm{w}$ festiwalowej przestrzeni jako formy wizualnie niezależne od otoczenia. Ich bycie niekoniecznie jest powiązane z analizami środowiskowymi, kompozycyjnymi, jakie zwykle dyktują rozwiązania przestrzenne w „normalnych”, niepokazowych dziełach ogrodowych(Myszka-Stąpór, 2017). Koncepcje ogrodów pokazowych są bardzo często prezentowane jako rysunki odręczne?

Bywa, że z festiwalu ogrodowego, który jest specyficzną wystawą sztuki, ogród pokazowy kopiowany jest do innej przestrzeni (Herman, 2011). Ogrody pokazowe są dobrym przykładem, który ukazuje rangę każdego poszczególnego elementu ogrodu. Według Jana Rylke (2010b) ogrody festiwalowe są pewnego rodzaju modelem dla współczesnych ogrodów prywatnych. Festiwale ogrodowe są więc wyznacznikiem trendów i tendencji w projektowaniu przestrzeni (RosłonSzeryńska, Pieńkowska, 2010).

W myśl założeń, że droga w ogrodzie jest kanwą dla kompozycji pozostałych form (Myszka-Stąpór, 2018) postanowiono przeanalizować formy dróg w założeniach historycznych i współczesnych, aby na tej podstawie zobrazować jakże współczesny, palący problem globalnej kwarantanny. Droga w ogrodzie nie tylko umożliwia przemieszczanie się, ale również strukturalizuje przestrzeń. Prowadzi do konkretnych miejsc i stref. Tworzy rdzeń ogrodu, pozwala oglądać otoczenie (Goodchild, 2008). Buduje kompozycję oraz łączy strefy funkcjonalne w ogrodzie. Nadaje rangę pozostałym elementom ogrodowym, może również określać granice wnętrz ogrodowych.

Historycy sztuki ogrodowej, analizując aspekty przemian formy, funkcji i treści różnych elementów ogrodowych wiele uwagi poświęcają drodze jako kanwie kompozycyjnej. Wyliczyć możemy wielu teoretyków podejmujących padania drogi z perspektywy sztuki ogrodowej: Ciołek (1957), Bogdanowski (1978), Majdecki (2006), Hobhouse (2020), Różańska (2008). Omawiają symbole oraz treści zapisane w drodze Majdecka - Strzeżek (2008), Szafrańska (1998, 2011). Jan Rylke (1995) w rozważaniach o tajemnicach ogrodów również wspomina o elementach ogrodowych. Wśród nich zwraca uwagę na drogi i ścieżki oraz ich układ. Droga jest u Rylkego archetypem rozpoznawalnym we wszystkich kulturach, w czasie i w przestrzeni. Z jednej strony odnosi się do znaczeń materialnych, z drugiej zaś, przypisuje się jej szereg metaforycznych treści, które odwołują się do wartości wyższych, metafizycznych (Ożóg, 2011).

Droga buduje kompozycję ogrodu, a od jej formy i zróżnicowania zależy, jaki styl dany ogród prezentuje. Możliwe jest uczytelnienie stylu i treści za pomocą rysunku drogi i dopełnienie tego rysunku takimi elementami jak kompozycje roślinne, architektura i elementy użytkowe, w ogrodach pokazowych traktowane jako środki wyrazu. A zatem można postawić tezę, iż: droga jest pierwotnie najistotniejszym elementem budującym formę i co za tym idzie treść dzieła ogrodowego.

Celem pracy jest określenie rangi drogi w ogrodzie oraz jej roli w budowaniu kompozycji ogrodu, co umożliwi opracowanie modeli ogrodów pokazowych inspirowanych sztuką ogrodową o, z góry określonej, tematyce „Kwarantanna”. W modelach ogrodów pokazowych droga będzie stanowiła kanwę kompozycyjną, a jej forma będzie charakteryzowała typ ogrodu, zależny od epoki historycznej.

\footnotetext{
${ }^{6}$ Festiwale ogrodowe organizowane są corocznie właściwie w każdym kraju. Wystawy ogrodów sztuki cieszą się dużą popularnością. Ogrody opowiadają, są o „czymś”. Wysycone są treścią. Niekiedy przez organizatorów festiwalu dyktowany jest motyw przewodni dla wszystkich przedstawień. Taka właśnie jest formuła festiwalu w Chaumont-sur-Loire.

${ }^{7}$ Rysunki odręczne prezentowane są w dokumentacjach festiwali m.in.: w Chaumont-sur-Loire, Chelsea Flower Show i In Garden w Lublinie, którego pierwsza edycja odbyła się w 2020 r. Żródło: http://www.domaine-chaumont.fr/fr/festivalinternational-des-jardins/archives; https://www.rhs.org.uk/shows-events/rhs-chelsea-flower-show, http://www.ingardeninlublin.com/, dostęp: 31.03.2021.
} 


\section{FORMA A TREŚĆ OGRODOWYCH PRZEDSTAWIEŃ}

Przegląd stanu badań obejmuje kwestie historii sztuki ogrodowej oraz współczesnych ogrodów pokazowych. Dla jasności wywodu należy zdefiniować pojęcie ogrodu pokazowego i znaczeń zakodowanych w formach elementów ogrodowych. W myśl rozważań zapisanych w monografii „Elementy ogrodowe. Ich forma, funkcja i znaczenie" (Myszka-Stapór 2014, s. 31): ogrody festiwalowe są opisywane jako ogrodowe dzieła sztuki. To samo określenie znajduje się również w opracowaniach Krzysztofa Hermana (2011), Kingi Zimowiec-Cieplik (2010), Jana Rylke (2010b, 2013b), Iwony Wiśniewskiej (2010). „Ogród sztuki”, ogród jako dzieło sztuki, „ogród - metafora”, realizowany najczęściej w ramach wydarzeń artystyczno-kulturalnych, którego celem nadrzędnym jest, oprócz samej warstwy estetycznej, uwydatnienie warstwy symbolicznej, przekazanie ukrytej treści, komunikatu autora, problemu czy zjawiska dotyczącego współczesnego świata. Ogród pokazowy powstaje by stać się inspiracją, wzorcem, modelem dla kreowania innych przestrzeni (Rosłon-Szeryńska, Pieńkowska, 2010). Natomiast znaczenie elementu ogrodowego - w myśl rozważań podjętych w monografii „Elementy ogrodowe. Ich forma, funkcja i znaczenie” (Myszka-Stąpór, 2014, s. 22): każdy element celowo zastosowany w ogrodzie ma zapisane znaczenie możliwe do odczytania (...).

Funkcja, forma oraz znaczenie elementów ogrodowych są ze sobą powiązane (Rylke, 2011a). O ich spójnym traktowaniu w kontekście dzieła ogrodowego piszą Janusz Bogdanowski (2000) oraz Stanisław Ossowski (1958), zwracając uwagę na to, że kompozycja powinna spełniać warunki formy, funkcji i treści powstającego dzieła. Treść w ogrodzie jest wyznacznikiem, według którego należy rozpatrywać ogrody nie zawężając tych przemyśleń tylko do kompozycji (Mitkowska, Łakomy, 2012). Dla autorek wartość naukowo-badawczą posiada nie tylko kompozycja ogrodu, ale także jego warstwa estetyczna, użytkowa i znaczeniowa. W opracowaniach Jeremiego T. Królikowskiego $(1978,1998)$ znaczenie zapisane w przestrzeni jest ujęte jako 'genius loci'. Podobny sposób interpretowania krajobrazu prezentował również Edward Bartman (2009) oraz Janusz Bogdanowski (2001). Agata Zachariasz (2010b), traktując o 'genius loci', opisuje i interpretuje treści ogrodów różnych kultur, podobnie jak Charles W. Moore, William J. Mitchell, William Turnbull Jr. (1993), którzy także analizują ogrody różnych kultur. Co ciekawe, Zachariasz podkreśla szczególnie relację między ilością elementów ogrodowych a typem ogrodu. Pisząc o współczesnych tendencjach i trendach w sztuce ogrodowej zwraca uwagę na kształt projektowanego ogrodu, który zależy od formy, funkcji i treści ${ }^{8}$. Według Spirn (1998) interpretowanie znaczeń i treści, które są zapisane w przestrzeni może być podstawą do tworzenia wytycznych projektowych. Treści krajobrazu nazywa 'językiem krajobrazu'. Określenie to odnajdujemy także w pracy Elżbiety Raszei (2009). Rozważania o treści i znaczeniu w ogrodzie podejmują także Jane Gillette, Susan Herrington, Laurie Olin, Marc Treib (2011). Herrington, jako projektantka ogrodów pokazowych festiwalu Jardin de Metis w Kanadzie, podtrzymuje pogląd na temat ogrodów, które są nośnikiem treści do odczytania. Treści ogrodów festiwalowych rozpatruje także Kinga Zinowiec - Cieplik (2010). Znaczenie elementów oraz treści ogrodów omawia również Iwona Wiśniewska (2010). Temat treści w ogrodach przydomowych podejmuje Beata Gawryszewska (2006), która przekonuje, że elementami nacechowanymi symbolicznie są przestrzenie, które łączą strefy ogrodowe, czyli tzw. „przestrzenie przejścia” oraz drogę honorową. Są one dobrym przykładem, który ukazuje rangę każdego poszczególnego elementu ogrodu.

Znaczenie drogi można rozpatrywać nie tylko w kontekście symbolicznym jako nośnik treści kulturowych, ale także w sensie użytkowo - funkcjonalnym, co widoczne jest w sposób szczególny w procesie projektowania. Jan Rylke (2017) w publikacji poświęconej zasadom projektowania, w jednym z rozdziałów jako pierwszy element, od którego powinno się zacząć projektowanie wymienia rozróżnienie głównego układu komunikacji od ścieżek przeznaczonych do spacerowania, co wskazuje na wyjątkowe, decydujące znaczenie drogi w kompozycji i funkcjonalności przestrzeni ${ }^{9}$.

8 Zachariasz (2009): „... forma, treść i funkcja, a co za tym idzie: stylistyka, semantyka, program, a także: technologia i materiały".

9 Jan Rylke (2017) w publikacji pt.: „Teoria i zasady projektowania dla architektów krajobrazu” w rozdziale poświęconym teoretycznym zasadom projektowania omawia istniejące zasady projektowania przestrzeni, którymi projektanci posługują się już od starożytności. Jako pierwszą zasadę podaje rozdzielenie komunikacji od spacerowania. Zwraca uwagę, iż do dzisiaj, przede wszystkim w większych założeniach ogrodowych, jak np. w parkach, drogi proste, geometryczne służą komunikacji, a ścieżki koliste są przeznaczone do spacerów. Autor podaje przykład warszawskiego Parku Ujazdowskiego oraz 
Według badań Izabeli Myszki - Stąpór (2014) droga jest elementem konstrukcyjnym ogrodu, tzn. droga jako osnowa umożliwia „zawieszenie na niej” różnych elementów akcentujących kompozycję, elementów rytmicznie ustawionych, dekoracyjnych, rabat.

\section{OGRODY SZTUKI HISTORYCZNE I WSPÓŁCZESNE}

Materiałem do badań wstępnych była ikonografia i ikonologia zebrana przez historyków sztuki ogrodowej. Wykorzystując dostępne opracowania planów ogrodów historycznych przygotowano schematy układów drogowych.

Jako materiał do analiz współczesnych układów drogowych wybrano dokumentację Festiwalu ogrodów w Chaumont-sur-Loire we Francji. Festiwal odbywa się corocznie, od 1992 roku. Ogrody prezentowane są na wydzielonej przestrzeni składającej się z około 26 odrębnych stanowisk. Do wzięcia udziału w wydarzeniu zapraszani są projektanci oraz artyści z całego świata. Wszystkie analizowane ogrody prezentują pewne cechy wspólne, które nadane są przez organizatorów festiwalu. Należą do nich: wielkość oraz kształt działki, ogrodzenie oraz temat, motyw przewodni. Różnorodność pomiędzy poszczególnymi ogrodami uwidacznia się w doborze elementów oraz w warstwie kompozycyjnej, które zależą nie tylko od idei, którą wyraża dany ogród, ale również od tematu edycji festiwalu (Myszka-Stapór, 2014). Ogrody festiwalu w Chaumont-sur-Loire zostały uznane za najwłaściwszy materiał do badań ze względu na:

- prezentowanie ogrodów jako dzieł sztuki, które przekazują istotne treści,

- możliwość interpretacji przekazywanych przez autorów treści i znaczeń dzięki dostępności komentarzy i opisów, rysunków i fotografii.

Jako metodę odczytywania znaczeń wykorzystano analizę ikonografii i ikonologii opracowaną przez Edwina Panofsky'ego (1971) oraz Jana Białostockiego (2008) opierającą się na ustaleniu tematów ramowych do analizy dzieła sztuki. Analizom poddano wszystkie dzieła zrealizowane w latach 2015-2019. Fotografie, filmy, komentarze i opisy ogrodów znajdują się w katalogu umieszczonym na stronie internetowej festiwalu (http://www.domaine-chaumont.fr/en/internationalgarden-festival- realizacje i projekty). Metoda interpretacji ogrodu pokazowego zapożyczona jest z historii sztuki, ponieważ zakładamy, że ogród pokazowy jest dziełem sztuki. Interpretacja przebiega zgodnie ze schematem: ustalenie tematów ramowych, analizy ikonologiczne i ikonograficzne, określenie elementów ogrodowych użytych jako środki wyrazu w dziele.

\section{ZNACZENIE DROGI W TREŚCI OGRODU}

We wszystkich analizowanych ogrodach historycznych oraz współczesnych występowała droga, która wyznaczała kompozycję, strefy funkcjonalne, dzieliła przestrzeń, niekiedy zmieniała swoją formę w plac lub zapętlała się. W wyniku analiz ikonografii ogrodów historycznych powstały schematy obrazujące układy drogowe charakterystyczne dla poszczególnych epok (ryc. 1).

Droga w ogrodach festiwalu w Chaumont-sur-Loire jest elementem strukturalizującym, tworzącym kompozycję. Wyznacza podziały i strefy. Prowadzi do miejsc. Wprowadza do ogrodu. Pozwala oglądać ogród. Wskazuje kolejne przystanki i zakątki, które składają się na zamierzoną koncepcję i wizję twórcy. Drogi niekiedy rozwijają się place. Wykonane są z różnych materiałów lub są połączeniem nawierzchni utwardzonej z meandrującym trawnikiem lub ścieżką żwirową. Odłączenie drogi od całości kompozycji spowodowałoby zagubienie proporcji, porządku, funkcji, a także głębokiej warstwy metaforycznej, którą są nacechowane ogrody pokazowe. Ich wartość kompozycyjno estetyczna, a wraz z nią metafizyczna byłyby w takim wypadku niemożliwe do odczytania i zinterpretowania. Wśród ogrodów festiwalu w Chaumont-sur-Loire występują drogi geometryczne oraz swobodne. Drogi geometryczne nieznacznie dominują nad swobodnymi. W latach 2015, 2016, 2017 ich liczba wyraźnie przeważała. W 2018 i 2019 roku zaczęły dominować ogrody z układem swobodnym, nieregularnym, z drogami o swobodnym i nieregularnym układzie. 
Tematy dla analizowanych ogrodów z ostatnich 5 lat festiwalu w Chaumont sur-Loire to: „Ogrody nadzwyczajne, ogrody kolekcji”, „Ogrody przyszłego stulecia”, „Flower Power - moc kwiatów”, „Ogrody myśli”, „Rajskie ogrody”. W ogrodach z trzech pierwszych edycji forma i treść drogi była rzadziej przywoływana w opisach, a w tematach związanych z rajem i myślami niemal w każdym opisie zdefiniowana była treść przypisana drodze. Wynika z tego, że droga była elementem notującym treści. W pierwszej edycji droga podkreślona była tylko dwa razy jako nośnik znaczeń. W drugiej edycji sześć razy. W trzeciej siedem razy. W czwartej w każdym ogrodzie - jeden z ogrodów miał nawet tytuł „Niekończąca się promenada” (Agathe Pichard, Agnès Emonet, Laurence VincentPichard, 2018). W każdym z opisów „Ogrodów myśli” droga była podkreślona jako ważnym element. W ostatniej $z$ analizowanych edycji w przeważającej większości droga przedstawiana była jako proces prowadzący do dobrostanu, który ma się kojarzyć z rajem oraz jest ważnym elementem kodującym znaczenia, związane z ludzkim postępowaniem i ludzkimi wyborami.

Z opisów ogrodów można odczytać rolę jaką droga pełniła w ich treści i kompozycji. Różne formy drogi były budowane z różnej substancji, a tym samym notowały zróżnicowane treści. Po pierwsze, przywoływano drogę jako pewien proces prowadzenia, podkreślano moment wejścia na drogę i zakończenia wędrówki. Pojawiło się też odmienne przedstawienie drogi jako ścieżki zapętlonej, która nie ma początku ani końca, co odwoływało się bezpośrednio do podejmowania życiowych decyzji i wolnej woli każdego człowieka. Drugi aspekt dotyczył różnicowania przestrzeni. W trzech spośród analizowanych ogrodów pojawił się motyw nici jako atrybutu powiązanego $z$ drogą, tak jak w micie o Ariadnie i Tezeuszu. Wykorzystując taką narrację, można twierdzić, że droga jak nić dzieliła ogród na różne przestrzenie o zwykle kontrastujących wartościach. Występowały też kontrasty, które pojawiały się przez samą wędrówkę po ogrodzie, w którym na drogę nakładane były kolejne przystanki, jak koraliki wplecione w jedną nić. Ogrodowe kontrasty związane $z$ drogą zapisane były w substancji - ogród suchy, ogród mokry, czarna lub biała kolorystyka, wzniesienie i zagłębienie terenu. Substancja drogi była podkreślana za pomocą materiałów oddziałujących na zmysł wzroku oraz dotyku jak np.: drewno, szkło, mech, piasek. Na drodze umiejscawiane były różne przeszkody, które oprócz swojej warstwy symbolicznej, budowały formę. Droga była niekiedy geometryczna, kręta, prosta, główna lub boczna, co dawało jej znaczenie archetypiczne i wskazywało różnice w sposobie i złożoności bytowania człowieka w świecie. Droga występowała również w formie labiryntu oraz spiralnej ścieżki, co symbolizowało podejmowanie decyzji przez człowieka, który ma prawo wybrać własną drogę. Droga była też zamknięta w tunel tak, by przechodzenie po niej było bardziej kontemplacyjne i odosobniające. W kilku ogrodach droga wznosiła się ku górze podkreślając $w$ ten sposób oś ziemia - niebo jako rodzaj sacrum. Tutaj droga była przedstawiona jako alegoria mądrości i doświadczenia, które wznoszą człowieka do góry.

\section{OGRÓD O KWARANTANNIE. WNIOSKI}

Na podstawie przeprowadzonych badań sporządzono modelowe koncepcje ogrodów pokazowych inspirowanych epokami z historii sztuki ogrodowej (ryc.2). Opracowano sześć modeli ogrodów, które reprezentują kolejno style ogrodowe epok historycznych. Tematem sporządzonych koncepcji ogrodów pokazowych jest „Kwarantanna”, ponieważ uznano, że w 2020 roku to najbardziej paląca tematyka. Droga jako element wiodący w temacie „Kwarantanna” ma ukazywać przejście przez ten trudny okres, jednocześnie odwołując się do historii sztuki ogrodowej. Wypracowane modele ogrodów pokazowych dowodzą, iż jest to możliwe. Posłużono się drogą jako głównym elementem wyrażającym treść na zadany temat i przedstawiono go w odniesieniu do epok historycznych. W tym miejscu należy podkreślić, iż ogrody pokazowe funkcjonują jako wyodrębnione z przestrzeni dzieła, niezależnie od otoczenia. Ich istnienie jest z założenia tymczasowe. Ich tworzenie niekoniecznie jest powiązane $z$ analizami środowiskowymi, funkcjonalnymi i kompozycyjnymi, jakie zwykle dyktują rozwiązania przestrzenne w „normalnych”, niepokazowych dziełach ogrodowych (Myszka Stąpór, 2017). Nawet koncepcje są bardzo często prezentowane jako rysunki odręczne ${ }^{10}$.

\footnotetext{
${ }^{10}$ Rysunki odręczne prezentowane są w dokumentacjach festiwali m.in.: w Chaumont-sur-Loire, Chelsea Flower Show i In Garden w Lublinie, którego pierwsza edycja odbyła się w 2020 r. Żródło: http://www.domaine-chaumont.fr/fr/festivalinternational-des-jardins/archives; https://www.rhs.org.uk/shows-events/rhs-chelsea-flower-show, http://www.ingardeninlublin.com/, dostęp: 31.03.2021.
} 
W modelu ogrodu inspirowanego Antykiem droga przechodzi przez perystyl. Kwarantannowa droga jest otoczona ścianami, zamknięta, odizolowana od świata. Pozostawione są w niej tylko okna, które jako jedyne umożliwiają obserwowanie otoczenia i dają namiastkę kontaktu ze światem. Zarówno droga jak i perystyl, zgodnie z tradycyjnymi wzorcami są wertykalnie otwarte, do światła nadziei.

Wirydarze w średniowieczu były miejscami przeznaczonymi głównie do modlitwy i kontemplacji. Wirydarz w przedstawionym modelu jest również miejscem odosobnienia i izolacji, jakiej wymaga kwarantanna. W centrum, na skrzyżowaniu ścieżek, znajduje się światło, które symbolizuje nadzieję, która ma szczególne znaczenie w kwarantannie. Wirydarz jest otoczony żywopłotem, który zamyka i izoluje przestrzeń.

Droga w modelu ogrodu renesansowego jest osią główną, która przechodzi przez centrum - przestrzeń w kwarantannie zamkniętą. W dalszej części ogrodu krzyżuje się ze ścieżkami poprzeczny$\mathrm{mi}$, budując tak partery ogrodowe. Jesteśmy blisko ziemi, w narzuconym schemacie uprawiamy ogród zamknięty, otoczony żywopłotem. W kwarantannie mamy tylko jedną drogę $-z$ domu do ogrodu.

Droga w ogrodzie barokowym jest osią główną kompozycji. Krzyżuje się drogami poprzecznymi, które rozchodzą się w układzie promienistym, tworząc "gęsią stopkę". Cały ogród jest zamknięty, otoczony żywopłotem, ale "górna" jego część, w której krzyżują się drogi została otwarta - analogicznie do tradycyjnych ogrodów barokowych, w których droga wiodła w kierunku otwarcia widokowego. Czyli może jest jakaś nadzieja na otwarcie?

Model ogrodu krajobrazowego powstał z połączenia ogrodów XVIII i XIX wieku, nazwanych w modelu ogrodem Oświecenia. Droga w ogrodzie krajobrazowym ma zróżnicowaną kompozycję. Bezpośrednio w otoczeniu „domu” jest geometryczna. W dalszej części ogrodu przyjmuje formę swobodną. W miejscu, gdzie symbolicznie został zaznaczony budynek znajdują się drzwi, które podkreślają moment przejścia. Kompozycja drogi została poprowadzona tak, by tworzyła zamknięty, zapętlony układ, czyli trudno określić jej koniec. Zapętlenie drogi jest nawiązaniem do kwarantanny. Człowiek w kwarantannie może poruszać się tylko po określonej przestrzeni. Droga zapętlona może być także interpretowana symbolicznie jako sytuacja bez wyjścia.

W ogrodzie modernistycznym układ komunikacji jest podporządkowany regułom minimalizmu, nie jest tak rozbudowany, jak w poprzednich modelach. Ogranicza się do jednej drogi głównej prowadzącej do dwóch ogrodów warzywnych, które są od siebie odgrodzone. Ogrody XX w. były przede wszystkim funkcjonalne, stąd zastosowanie w koncepcji tylko roślin użytkowych, które podkreślają tę funkcję. Dwa ogrody warzywne są celowo od siebie oddzielone. Jest to nawiązanie do kwarantanny, która wymaga odosobnienia i zamknięcia się na otoczenie.

Konkludując znaczenie drogi jako elementu w ogrodzie należy zaakcentować jej wagę w aspektach komunikacji, formy i treści. Układ drogi identyfikuje styl epoki w sztuce ogrodowej, a także stanowi ramy kompozycji ogrodu. Droga, dzieląc przestrzeń strukturalizuje ją. Poprzez zamierzoną zmianę formy i substancji drogi twórcy ogrodowych dzieł notują w nich różne znaczenia, uwikłane w różnorakie tematy ramowe i stylistyki. Droga jest elementem całej kompozycji. Ma wpływ na jej odbiór i ostateczną formę. Co więcej, odgrywa kluczową rolę w budowaniu harmonii i balansu. To ona porządkuje przestrzeń. Prowadzi do konkretnych miejsc i stref, przez co nadaje rytm i określa rangę pozostałych elementów ogrodowych. To od jej układu w dużej mierze zależy rozplanowanie wszystkich wnętrz ogrodowych. To z jakiej perspektywy będzie oglądany ogród zależy przede wszystkim od tego w jakich kierunkach poprowadzone będą ścieżki. Układ komunikacji to szkielet ogrodu, jego baza, plansza, do której dodaje się kolejne komplementarne komponenty. Często to właśnie droga wyznacza granice, jest więc jednocześnie ramą ogrodu, która otwiera i zamyka kompozycję.

Wyniki pracy mogą posłużyć do dalszych interpretacji drogi jako elementu ogrodowego, interpretacji całych założeń ogrodowych oraz do dalszych badań. Umożliwiają klasyfikowanie ogrodów na podstawie drogi oraz ułatwiają rozpoznawanie stylów historycznych po układzie komunikacji. Przedstawione modele mogą być inspiracją do kreowania innych przestrzeni, a także stanowić wytyczne do prowadzenia drogi w ogrodach inspirowanych historią ogrodów. 


\section{BIBLIOGRAPHY}

Bartman E., 2009. Istota architektury krajobrazu Sztuka kształtowania ogrodów, parków i krajobrazu otwartego, [w] Szumański M. (red.), Diariusz Katedry Architektury Krajobrazu, zeszyt 6, Ogrody w twórczości Edwarda Bartmana Wydanie specjalne z okazji 80. urodzin Profesora, Wydawnictwo SGGW, Warszawa, s. 12 - 21

Białostocki J., 2008. Wybór pism estetycznych, Universitas, Kraków

Bogdanowski J. 2000. Polskie ogrody ozdobne, Wydawnictwo Arkady, Warszawa

Bogdanowski J. 2001. Czytanie krajobrazu, [w] Michałowski A. (red.) Krajobraz kulturowy warsztaty dla nauczycieli i metodyków. Ośrodek Ochrony Zabytkowego Krajobrazu, Warszawa, s. 17 - 35

Ciołek G., 1957. Ogrody Polskie. red. I uzup. J. Bogdanowski, Wydawnictwo Arkady, Warszawa

Gawryszewska B. J. 2006. Historia i struktura ogrodu rodzinnego, Wydawnictwo SGGW, Warszawa

Gawryszewska B., Myszka-Stąpór I., Herman K., Rylke J. 2018: Ogrody w teorii i praktyce Pracowni Sztuki Ogrodu i Krajobrazu, Warszawa, Stowarzyszenie Genius Loci, 120 s., ISBN 978-83-9529-560-7

Goodchild P.H., 2008. Opieka nad dziedzictwem ogrodowym i krajobrazowym: rola edukacji uzupełniającej, [w] Rylke J., Kaczyńska M., Sikora D. (red.), Zielone światy. Zabytkowy krajobraz kulturowy, parki, ogrody, cmentarze i inne formy zaprojektowanej zieleni. Ich ochrona, konserwacja, restauracja i użytkowanie społeczne. Wydawnictwo SGGW, Warszawa, s. 137 - 156

Herman K., 2011. Ogrody tymczasowe w przestrzeniach kolektywnych, Wydawnictwo Sztuka Ogrodu Sztuka Krajobrazu, Seria: doktoraty Katedry Sztuki Krajobrazu, Warszawa

Herrington S. 2011. Gardens can mean. [w:] Treib M. (red.), Meaning in Landscape Architecture \& Gardens, Routledge, Taylor \& Francis Group London and New York

Hobhouse P. 2020. The Story of Gardening, Princeton Architectural Press

Królikowski J. T. 1978. Elementy semiotyczne dzieła architektury, w Pelc J., Studia semiotyczne, nr VIII, Zakład Narodowy im. Ossolińskich, Wydawnictwo Polskiej Akademii Nauk, Wrocław - Warszawa - Kraków Gdańsk

Królikowski J. T. 1998. Zastosowanie koncepcji Norberga-Schulza do badań nad architekturą krajobrazu, praca doktorska, WOiAK, wydruk komputerowy, Biblioteka Główna SGGW

Majdecka-Strzeżek A. 2008. Ukryta symbolika ogrodów, w Zieleń miejska, nr 11, Abrys, Wydawnictwa komunalne, Warszawa, s. 18-19

Majdecki L. 2006. Historia ogrodów, tom I, II, Wydawnictwo PWN, Warszawa

Mitkowska A., Łakomy K. 2012. O użytkowaniu ogrodu. Wprowadzenie w problematykę, Czasopismo techniczne, 8-A/2012, Wydawnictwo Politechniki Krakowskiej, Kraków

Moore Ch. W., Mitchell W. J., Turnbul W. J., 1993. The poetics of garden, The MIT press

Myszka-Stąpór I. 2014. Elementy ogrodowe. Ich forma, funkcja i znaczenie. Monografia Sztuka Ogrodu Sztuka Krajobrazu 3/2014, Wydawnictwo Katedra Sztuki Krajobrazu, SGGW, Warszawa

Myszka-Stąpór I. 2017: Krajobrazy w sztuce ogrodowej. Zeszyty Naukowe Uczelni Vistula, nr 53 (2), s.166 175

Myszka-Stąpór I. 2017: Ogród: wprowadzenie. W: Projektowanie ogrodu i krajobrazu : wybór tekstów / Gawryszewska Beata [i in.] (red.), 2017, Warszawa, Wydawnictwo SGGW, s.7-9, ISBN 978-83-7583-728-5

Ossowski S., 1958. U podstaw estetyki. PWN Warszawa

Ożóg K. 2011. Metafora życia ludzkiego jako drogi - aspekty językowe i kulturowe, w Adamowski J., Smyk K. (red.), Droga w języku i kulturze. Analizy antropologiczne, Wydawnictwo Uniwersytetu Marii CurieSkłodowskiej, Lublin

Panofsky E., 1971. Studia z historii sztuki, Państwowy Instytut Wydawniczy, Warszawa

Pichard A., Emonet A., Vincent-Pichard L., 2018: Niekończąca się promenada, Ogrody myśli, http://www.domaine-chaumont.fr/fr/festival-international-des-jardins/archives/edition-2018-jardins-de-lapensee, dostęp/access: 10.03.2021

Raszeja E. 2009. Krajobraz kulturowy - relikt przeszłości czy żywe dziedzictwo? Wnioski z badań na terenie wsi Sławsko i Wrześnica, w Rączkowski J., Sroka J. (red.), Historia i kultura ziemi Sławińskiej tom IX Krajobrazy okolic Sławna, Sławno, s. 206-225

Rosłon-Szeryńska E., Pieńkowska M. 2010. Styl współczesnych ogrodów przydomowych. Odzwierciedlenie kwalifikacji zawodowych i warsztatu projektanta w Polsce, w Szulczewska B., Szumański M. (red.), Horyzonty Architektury krajobrazu. Język architektury krajobrazu, Wydawnictwo Wieś Jutra, Warszawa, s. $85-95$ 
Różańska A. 2008. Historia europejskiej sztuki ogrodowej, w Różańska A., Krogulec T., Rylke J. Ogrody. Historia architektury i sztuki ogrodowej, Wydawnictwo SGGW, Warszawa, s. $42-142$

Rylke J. 1995. Tajemnice ogrodów, Wydawnictwo Kanon, Warszawa

Rylke J. 2010b. Ciało i Dusza. Festiwal ogrodowy w Chaumont-sur-Loire w 2010 roku, Wydawnictwo Sztuka Ogrodu Sztuka Krajobrazu (wersja online)

Rylke J. 2011a. Krajobraz kulturowy. Mapy znaczeń, w Plit. J. (red.), Prace Komisji Krajobrazu Kulturowego PTG nr 15: Niematerialne wartości krajobrazów kulturowych, Wydawnictwo Komisja Krajobrazu Kulturowego Polskiego, Sosnowiec, s. 278-287

Rylke J. 2013b. Ogrody sztuk, w Rylke J. (red.), Sztuka Ogrodu Sztuka Krajobrazu. Wydawnictwo Katedra Sztuki Krajobrazu, SGGW, Warszawa

Rylke J. 2017. Teoria i zasady projektowania dla architektów krajobrazu, w Rylke J. (red.), Sztuka Ogrodu Sztuka Krajobrazu. Wydawnictwo Katedra Sztuki Krajobrazu, SGGW, Warszawa

Spirn A. W., 1998. Language of landscape, Yale University Press, New Haven and London

Szafrańska M. 1998. Ogród. Forma, symbol, marzenie. Wydawnictwo Zamku Królewskiego Arx Regia, Warszawa

Szafrańska M. 2011. Człowiek w renesansowym ogrodzie, Miniatura, Kraków

Treib M. 2005. Settings and Stray Paths: Writings on Landscapes and Gardens, Routledge

Treib M. 2011. Settings and Stray Paths: Writings on Landscapes and Gardens, Routledge

Wiśniewska I., 2010. Znaki w architekturze.Praktyka projektowa na wystawie Chelsea Flower-Show. [w] Szulczewska B., Szumański M. (red.), Horyzonty Architektury krajobrazu. Język architektury krajobrazu, Wydawnictwo Wieś Jutra, Warszawa, s. 32-39

Zachariasz A. 2010b. O różnym pojmowaniu genius loci w ogrodach, Czasopismo techniczne 5-A/2010 Zeszyt 13 rok 107, Wydawnictwo Politechnika Krakowska, Kraków, s. 14-30

Zinowiec-Cieplik K. 2010. Moda i styl we współczesnej sztuce ogrodowej, w Gawryszewska B. J. (red.), Ogród za oknem - dzieło sztuki. Wydawnictwo Sztuka Ogrodu Sztuka Krajobrazu, Warszawa, s. 28-31

http://www.domaine-chaumont.fr/en/international-garden-festival/archives, dostęp/access: 10.03.2021

\section{AUTHOR'S NOTE}

Izabela Myszka is a scientific researcher in contemporary garden art, garden sculpture, show gardens, and therapeutic gardens. Additional research and design topics are related to revitalized spaces.

Kontakt | Contact:, +48225932216.

Katarzyna Augustyniak is a graduate of Landscape Architecture, specializing in the Department of Landscape Art. Master's thesis "Road as an essential element of a garden composition. Transformations of Form ". This article is a synthesis of information from the thesis.

\section{O AUTORZE}

Izabela Myszka naukowo zajmuje się współczesną sztuką ogrodową, rzeźbą w ogrodzie, ogrodami pokazowymi, ogrodami terapeutycznymi. Dodatkowe tematy badawcze i projektowe związane są z przestrzeniami rewitalizowanymi.

Katarzyna Augustyniak absolwentka Architektury Krajobrazu, specjalizacja w Katedrze Sztuki Krajobrazu. Praca magisterska „Droga jako istotny element kompozycji ogrodowej. Przemiany formy". Niniejszy artykuł jest syntezą informacji z pracy magisterskiej.

Contact | Kontakt: izabela myszka@sggw.edu.pl; augustyniak.kd@gmail.com 